\title{
BABOON (PAPIO ANUBIS) AS AGENT OF HABITAT REGENERATION WITHIN THE MARGUBA RANGE OF OLD OYO NATIONAL PARK, NIGERIA
}

\author{
Oyeniyi, Oreoluwa John \\ Jayeola Omotola Abiola \\ Department of Forestry and Wildlife Management Department of Forestry and Wildlife Management \\ Federal University of Agriculture, Abeokuta, Nigeria Federal University of Agriculture, Abeokuta, Nigeria \\ Yisau Muideen Alade \\ Department of Forestry and Wildlife Management Department of Ecotourism and Wildlife Management \\ Federal University of Agriculture, Abeokuta, Nigeria Federal University of Technology, Akure, Nigeria
}

Abstract-- Tropical forests and the animals they support are being threatened by rapid rates of forest conversion and degradation. The impact of Papio anubis on habitat regeneration within the marguba range of Old Oyo National Park was assessed, in-order to determine their role in seed dispersal. Five existing transects within the Marguba range of the Park were identified and marked at every $1 \mathrm{~km}$ for data collection. Population structure of Baboon troops sighted along the transects were recorded, feacal droppings and soil samples were collected along the transects. Vegetation assessment were carried out at $15 \mathrm{~m}$ radius around each feacal sample. Each feacal sample collected was examined for visible presence of seeds, and number of each seed extracted was recorded and sowed into its corresponding extraction site soil for germination trial. Replica of each seed extracted was procured from Forestry Research Institute of Nigeria and treated appropriately before sowing, as control. A total of twenty Papio anubis from four troops were sighted, in four of the five transects. A total of eight seed species; Blighia sapida (8), Vitex donianan (5), Vitellaria paradoxa (13), Citrus pomelo (10), Piliostigma thonningii (16), Parkia biglobosa (10), Sarcocephalus latifolius (14) and Detarium macrocarpum (4) were found in the 18 feacal samples collected. Piliostigma thonningii and Vitellaria paradoxa trees were found to have the highest abundance, while Sterospermum kunthianum, Ficus thonningii, Pterocarpus erinacus, Securidaca longipedunculata and Grewia mollis were the least abundant during the vegetation assessment around feacal sites in the park. Seeds extracted from all the feacal samples showed reduction in weight compared to the control seeds. Blighia sapida, Vitex donianan, Citrus pomelo, Piliostigma thoningii, Sacrocephalus latifolius, Parkia biglobosa and Detarium macrocarpum were found to have a percentage germination rates of $39,50,50,44,36,50$ and 50 respectively, while Vitellaria paradoxa did not germinate. Days before emergence was shorter in seeds of Vitex doniana (14-19 days) and Daterium macrocarpum (7-8 days) compared to their control seed (25-26 days and 9 days respectively), while days before emergence in seeds of Piliostigma thonningii (14-20 days), Parkia biglobosa (14-18 days), Sacrocephalus latifolius (21-24 days) and Citrus pomelo (8-14 days) were longer compared to their control seed (10-11, 8-10, 14 and 7 days respectively). The days before emergence for Blighia sapida was the same with that of its control (16 days). This study concluded that $P$. anubis were agent of seed dispersal. Also, seeds that moved through the gut of Baboons has shown to remain viable, but its movement along the gut does not appear to effectively affect its dormancy. 


\section{International Journal of Engineering Applied Sciences and Technology, 2020 \\ Vol. 4, Issue 9, ISSN No. 2455-2143, Pages 299-323 \\ Published Online January 2020 in IJEAST (http://www.ijeast.com)}

Keywords-- Ecosystem, Seed dispersal,
Deforestaton, Habitat loss, Fragmentation,
Frugivores

\section{INTRODUCTION}

The natural home of a plant, animal or other organism is understood as its habitat and maintaining this space is crucial to the survival of both individuals and species (World Wide Fund for nature, (WWF, 2017). But unfortunately, the habitats of large numbers of the Earth's plant and animal species are under threat due to the impact of man (WWF, 2017). Natural habitat for animal and plant species is being destroyed at an alarming rate. Nigeria is a home to an upscale diversity of forest and wildlife, including a minimum of 899 species of birds, 274 mammals, 154 reptiles, 53 amphibians, and 4,715 species of higher plants (Connell, 1978). Nevertheless, Nigeria's forest is one of the most threatened on the planet due to high population growth rates, conversion for subsistence and industrial agricultural, and logging (Butler, 2014). The country's rainforest is fast declining, according to the United Nations (2012), Nigeria lost nearly 80 percent of its old-growth forests between 1990 and 2005 , giving the dubious distinction of having the highest deforestation rate of natural forest on the earth during that period. Also, according to FAO (2005), Nigeria had the highest of deforestation in the world as of 2005. Between 2000 and 2005, the country lost $55.7 \%$ of its primary forest. Between 1990 and 2000 Nigeria lost a mean of 409,700 hectares of forest per annum which equals to a mean annual deforestation rate of $2.38 \%$. Between 1990 and 2005, in total, Nigeria lost $35.7 \%$ of its forest cover, or around $6,145,000$ hectares. Therefore, there is need to search for sustainable solutions to these high rates and look extensively into a way of habitat regeneration, and a way to keep the forest resources alive with human's poor conservation practice. Hence, other means of dispersing seeds in natural habitat and forests, through wild animals like primates, which could be omnivorous (having the tendency to protect themselves and serve in habitat regeneration i.e. dispersing of seeds) in diet.

Baille et al., (2004) emphasizes that habitat loss and fragmentation are major threats to terrestrial biodiversity. The planet's human population has doubled in the past 50 years and the pressure to house and feed more than eight billion people has increased dramatically, thereby causing an incursion into previously pristine natural habitats. Animals left residing in degraded forests or forest fragments may face reduced food resources and loss of cover or hiding places, and in some cases pressure from invasive species. Populations may also be more vulnerable in the event of natural disasters such as hurricanes, and changes in habitat brought about by global climate change, such as seasonal droughts (Malhi et al., 2008). Deforestation, which is the main reason for habitat degradation, is the conversion of forest to an alternative permanent non-forested land use such as agriculture, grazing or urban development (van Kooten and Bulte, 2000). Deforestation is primarily an issue for the developing countries of the tropics (Myers, 1994) because it is shrinking areas of the tropical forests (Barraclough and Ghimire, 2000) causing loss of biodiversity and enhancing the atmospheric phenomenon (Angelsen et al., 1999). One method used to counteract the loss of forest is land restoration and subsequent habitat regeneration. Protection of the remaining intact patches would be insufficient to save the ecosystem; therefore, knowledge of natural succession in tropical forest is crucial to reclaim disturbed land (Sabogal, 1992). Seed dispersal is important for the long-term survival of forests (Nuñez-Iturri et al., 2008), and as such need's consideration and incorporation into conservation plans. Vertebrate frugivores, in particular primates, play an important role in the regeneration of tropical forest habitats through their roles as seed dispersers (Oliveira and Ferrari 2000) and understanding this role in conservation and restoration projects is highly valuable. Moreover, maximizing natural seed dispersal services has the potential to be a costeffective approach to conservation efforts (Wunderle, 1997; Duncan and Chapman, 1999). Kunz and Linsenmair (2008), suggested that the role of baboons as seed dispersers may increase as populations of elephants and hornbills decline in the savanna-forest mosaic of West Africa. Objective: To determine the role of baboon in habitat regeneration within the Marguba range of Old Oyo National Park, Nigeria and also compare the regeneration capacity of seeds extracted from baboon feaces and seed from seed store.

\section{METHODS}

\section{Study Area}




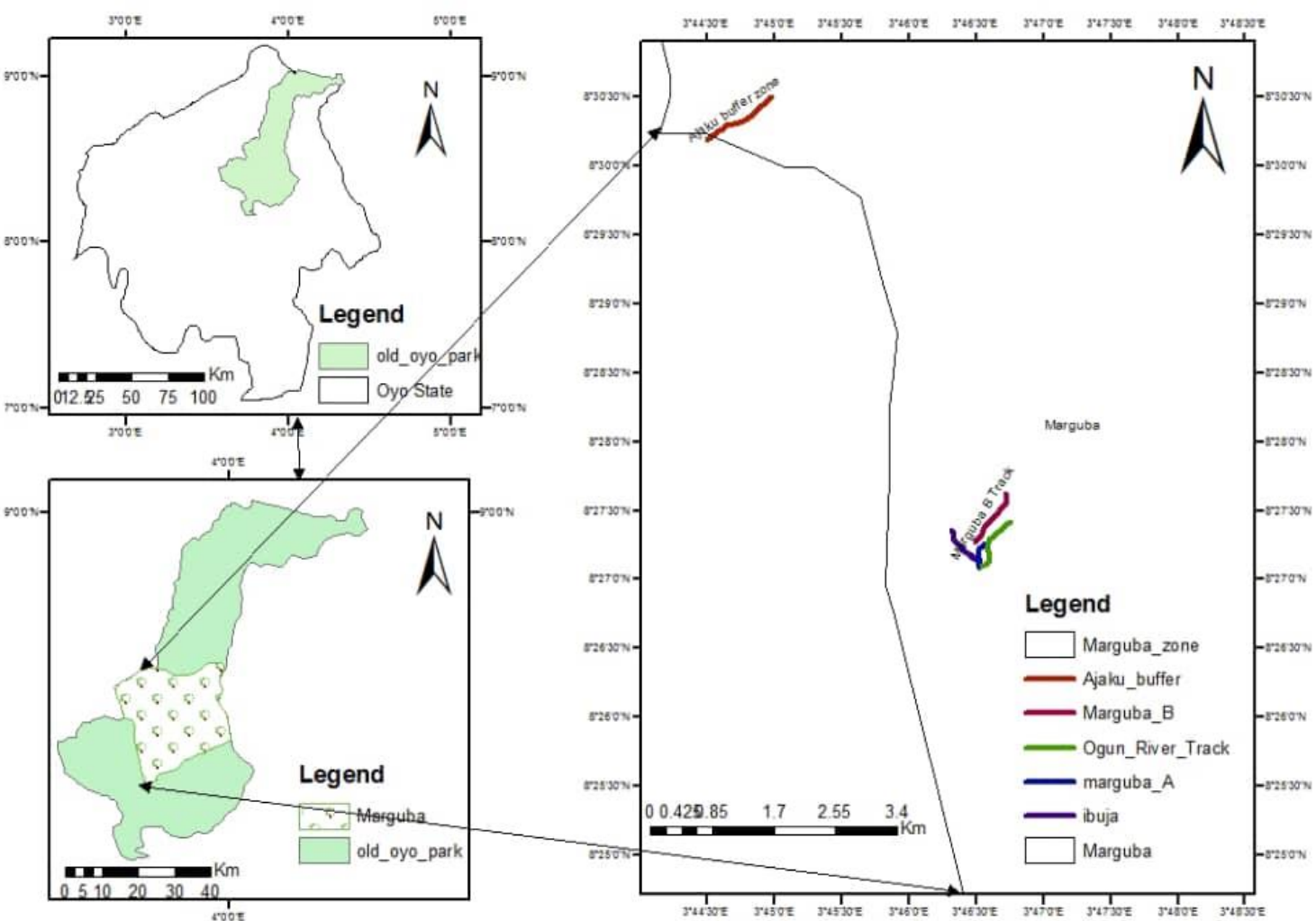

The study was conducted in the Marguba range of Old Oyo National Park, Oyo State, Nigeria. The range was purposively selected because it was reported that the range has the highest abundance of Baboon in the park (Adetoro et al., 2011). This range is also described as heartbeat of the park. The park has a saxophone-like shape. It is bordered in the North by Kwara State, in the South by Ikoyi while in the western part it is bordered by towns such as Igbope and Sepeteri. The Old Oyo National Park lies between latitudes $8^{\circ} 15^{\prime}$ and $9^{\circ} 05^{\prime} \mathrm{N}$ and longitudes $3^{\circ} 35^{\prime}$ and $4^{\circ} 20^{\prime} \mathrm{E}$. The location has inevitably placed the park at a vantage position of abundance acreage also as diverse wildlife and cultural/historical settings. The park covers a land area of approximately 251,200ha making it the fourth largest park in Nigeria after Gashaka Gumti National Park (673,100ha), Kainji National Park (538,000ha), Cross River National Park (400,000ha). The park is made up of five ranges namely: Marguba range in Sepeteri, Oyo lle range in lgbeti, Yemoso range in lkoyi-lle, Tede Park in Tede, Sepeteri range in lgboho. It provides a thriving habitat for a range of wild fauna
Figure 1: Map showing the Location of Transect used within the park for Data Collection

among which are primates that inhabit the guinea savannah.

The park covers $2,512 \mathrm{~km}^{2}$, mostly of lowland plains at a height of $330 \mathrm{~m}$ and $508 \mathrm{~m}$ above sea level. The southern part is drained by the Owu, Owe and Ogun Rivers, while the northern sector is drained by the Tessi River. Outcrops of granite are typical of the north eastern zone of the park, including at Oyo-lle, with caves and rock shelters within the extreme north. The central axis of the park has scattered hills, ridges and rock outcrops that are suitable for mountaineering. The Ikere Gorge Dam on the Ogun river provides water recreation facilities for tourists (Nigeria National Park Service, (NNPS, 2014). The purpose was mainly for conservation, preservation and protection of our natural resources. The Park is rich in Fauna resources with significant species of which are the Buffon's kob (Kobus kob), Roan Antelope (Hippotragus equines), Western hartebeest (Alcelaphus buselaphus), Bush buck (Tragelaphus scriptus), Baboon (Papio anubis), Patas monkey (Erythrocebus patas), Grimm's duiker (Slyvicappra 


\section{International Journal of Engineering Applied Sciences and Technology, 2020 \\ Vol. 4, Issue 9, ISSN No. 2455-2143, Pages 299-323 \\ Published Online January 2020 in IJEAST (http://www.ijeast.com)}

grimmia), Lion (Pantera leo), War thog (Phacochoerus aethiopicus), Water buck (Kobus defasa), Red flanked Duiker (Cephalophus rufilatus), Black and White Colobus monkey (Colobus vellerous), Green monkey (Cercopithecus athieops) and many more, with variety of birds (Nigeria Galleria, 2017). Vegetation of the Old Oyo National Park has been classified as Southern Guinea Savanna (Keay, 1959). However more intense studies classify the Southern portion of the vegetation as Forest savanna Mosaic with wooded savanna containing relic of Moist Semi decidious forest, grading northwards into drier Mixed Leguminous Wooded Savanna with a continuous lower stratum of perennial grasses (Charter, 1970).

\section{Sample Collection}

From July 2018 to August 2018, we surveyed Five existing track (either Jeep or foot) within the Marguba range of the Old Oyo National Park. The five tracks were traversed daily from $7.00 \mathrm{am}$ to $12.00 \mathrm{pm}$ and from $4.00 \mathrm{pm}$ to $7.00 \mathrm{pm}$ (local time) with an average walking speed of $1.0 \mathrm{~km} / \mathrm{hr}$ covering an estimated $1 \mathrm{~km}$ distance per track. Periods of walking were interspersed with periods of 'silent', 'watch' and 'wait' in order to increase the possibility of detecting animals that might hide or flee upon the approach or movement of observers. The coordinates of the tracks were taken using a Global Positioning System (GPS) at the beginning and end of the track. The individual animals directly encountered were counted. A Binocular (10x42mm) was used to observe and detect the presence of animals. Animals sighted were identified as outlined and described by Jean and Pierre (1990). Information was collected on groups of animals sighted which included species, sex, sighting distance $(\mathrm{m})$ and population structure such as, number of adult males, females, sub-adult males, sub-adult females, and juveniles. Five basic assumptions were made as recommended by Burnham (1980), Seber (1982) and Dunn (1993). Each Baboon troop encountered were observed and stalked for thirty minutes; before another one present can be stalked. The aim was to enhance chances of collecting fresh fecal samples from different troop members. Each time the focal animal defecated, the fecal clumps were collected. The dung dropped by Baboon detected along the track was also collected and added-on to the fecal samples collected during observations. Each independent fecal sample was put in a separate plastic bag, differently labelled and kept in an ice pack to prevent the fecal clump from disintegration before seed extraction. A 15 meters' radius circular plot assessment was carried out on every site of fecal collection with the aim of identifying the Plant species in the habitat. Moderately deep (50 centimeter) soil sample was collected from each sampled site and latter sterilized in an oven at $100^{\circ} \mathrm{C}$ for 24 hours to kill the seed within the bank, and transferred into separate polythene nursery bag $(20 \mathrm{~cm}$ deep), and allowed to rest for 7 days. At the end of each sampling day, every fecal samples collected were searched for visible seed constituents, seeds present in each collected sample were washed, and weighed using a weighing balance. The density of Baboon scats was determined by measuring the total weight of the fecal sample to the weight of the seeds extracted from each, the number of seeds in each Baboon scat was counted and identified to species level. Extracted seeds were visually examined for damage and coded as either whole (undamaged to the human eye or had shallow scratches) or destroyed (occur in species identifiable pieces). The seeds were then dried under room temperature, and stored for germination trials. Each extracted seed was sown into its respective sampled site soil sterilized and kept moderately moist by watering twice a day. It was tagged First group.

Replicate of each identified seed species extracted from Baboons dung was obtained at the Forest Research Institute of Nigeria (FRIN) seed store. River side sand was also obtained and sterilized in an oven at $100^{\circ} \mathrm{C}$ for 24 hours, and also transferred into different polythene nursery bag $(20 \mathrm{~cm}$ deep). Each seed specie obtained from FRIN was treated (to enhance optimum regeneration as a unit for measurement) and then broadcasted in separate sterilized River side soil in the polythene nursery bag. This serves as the control experiment and was tagged Second group.

The first and second group were checked twice a day (morning and evening) to record any seed that germinated. The growth rate (height) of successful seedling was recorded at intervals in each of the nursery bag and groups. The total number of successful seedlings in all the nursery bags were determined after 2 months. The approximated percentage of germinated seeds in relation to the number of extracted seeds was determined. The percentage Germination of seeds was calculated thus:

\section{$\%$ Germination of Seeds = \\ $\frac{\text { Total Number of Germinated Seeds }}{\text { Total Number of Extracted Seeds }} \times 100 \%$}

Seed species collected from the Federal Research Institute of Nigeria (FRIN), passed through different treatment based on research studies before planting, as shown in table 1. 
International Journal of Engineering Applied Sciences and Technology, 2020

Vol. 4, Issue 9, ISSN No. 2455-2143, Pages 299-323

Published Online January 2020 in IJEAST (http://www.ijeast.com)

Table 1:Treatment Administered to Replicate Seed Species Collected from Forest Research Institute of Nigeria (FRIN), Before Sowing

\begin{tabular}{|c|c|c|}
\hline \multirow[t]{2}{*}{ Seed } & \multicolumn{2}{|c|}{ Treatment } \\
\hline & No Treatment & Scarification \\
\hline Blighia sapida & $+($ Koenig, 2012) & \\
\hline Vitex donianan & & $+($ Fern, 2014) \\
\hline Vitellaria paradoxa & + (Nikiema and Umali, 2007) & \\
\hline Citrus pomelo & + (Herzog et al., 1994) & \\
\hline $\begin{array}{l}\text { Piliostigma thonningii } \\
\text { Parkia higlohosa }\end{array}$ & & $+($ Amonum et al., 2016) \\
\hline $\begin{array}{l}\text { Parkia biglobosa } \\
\text { Sarcocephalus }\end{array}$ & + (Kouvate and Van Damme, & $+($ Burkill, 1997) \\
\hline latifolius & 2006) & \\
\hline $\begin{array}{l}\text { Detarium } \\
\text { macrocarpum }\end{array}$ & & + (Lamessa, 2010) \\
\hline
\end{tabular}

\section{Statistical Analysis}

Duncan Multiple Range Test was used to determine the difference in mean of weights obtained from measurement of seeds from Forest Research Institute of Nigeria (FRIN).

\section{RESULT}

\section{Population Structure of Baboon}

Four baboon troops were sighted, the First, Second, Third and Fourth troop composed of Five, Three, Seven and Five members respectively (Table 2).

\section{Habitat Utilization of Baboon based on Feacal point Extraction}

A total of Eighteen (18) fecal samples were collected at different locations within the Five tracks used (Table 3). The samples were labelled (F1, F2, F3, F4, F5, F6, F7, F8, F9, F10, F11, F12, F13, F14, F15, F16, $\mathrm{F} 17, \mathrm{~F} 18$ ) based on their sequence in collection (that is, the first fecal sample collected was labelled F1 and subsequent collection following the same trend in labelling respectively).
Vegetation Assessment around Feacal Collection Sites

Feacal extract F1 composed of 5 different species of trees of 5 different families within a 15 -metre radius around the defecated site. F2 was found to have 5 Species with two of the species sharing the same member thereby making 4 families (Table 4). Appendix 1 shows the specie names vegetation assessed within each plot of feacal extract and their family names are shown in Appendix 2.

\section{Composition of Seeds voided by Baboon}

A total of eight (8) species were identified in all the fecal sample collected (Table 5), with a total seed count of 86 seeds. Seven of the eight tree species has presence within the park (Table 13). However, Citrus pomelo whose seed was also identified from feacal samples (Table 5) was not encountered during the vegetation assessment within the habitat used for feeding by Baboons within the park (Table 13). 
International Journal of Engineering Applied Sciences and Technology, 2020

Vol. 4, Issue 9, ISSN No. 2455-2143, Pages 299-323

Published Online January 2020 in IJEAST (http://www.ijeast.com)

Table 2:Population Structure of Baboon troops within the Park

\begin{tabular}{|c|c|c|c|c|c|c|c|c|c|}
\hline \multirow[t]{2}{*}{ Track } & \multirow{2}{*}{$\begin{array}{l}\text { No of } \\
\text { Adults }\end{array}$} & \multirow{2}{*}{$\begin{array}{c}\text { No of } \\
\text { Juvenile }\end{array}$} & \multirow[t]{2}{*}{ Total } & \multirow{2}{*}{$\begin{array}{c}\% \\
\text { Abundance }\end{array}$} & \multicolumn{2}{|c|}{ Sex } & \multirow[t]{2}{*}{ Activity } & \multirow{2}{*}{$\begin{array}{l}\text { Dropping collected } \\
\text { from troop }\end{array}$} & \multirow{2}{*}{$\begin{array}{c}\text { Location From Track } \\
\text { (Metres) }\end{array}$} \\
\hline & & & & & Male & Female & & & \\
\hline Ibuya-Ipade Aya & 3 & 2 & 5 & $25 \%$ & Un & Un & Running & None & $420 \mathrm{~m}$ from base \\
\hline \multicolumn{10}{|l|}{ Track } \\
\hline Track Along & 2 & 1 & 3 & $15 \%$ & 2 & 1 & Playing & F11 & Track Starting point \\
\hline \multicolumn{10}{|l|}{ River Ogun } \\
\hline Marguba B Track & 0 & 0 & 0 & 0 & - & - & - & - & - \\
\hline Marguba A & 4 & 3 & 7 & $35 \%$ & Un & Un & Running & None & $300 \mathrm{~m}$ from Starting point \\
\hline \multicolumn{10}{|l|}{ Track } \\
\hline Ajaku Buffer & 3 & 2 & 5 & $25 \%$ & 2 & 3 & Playing & F6, F7 & Track Starting point \\
\hline \multicolumn{10}{|l|}{ Zone } \\
\hline Total & 12 & 8 & 20 & & & & & & \\
\hline
\end{tabular}

*Un - Unidentified, F - Feacal sample 
Table 3: Feacal Extract Per Transect

\begin{tabular}{lc}
\hline TRANSECT & FEACAL SAMPLES \\
\hline Ibuya - Ipade Aya Transect & $\boldsymbol{F 3 , ~ F 4 , ~ F 9 , ~ F 1 0 . ~}$ \\
Transect Along River Ogun & $\boldsymbol{F 1 1 , ~ F 1 4 , ~ F 1 7 . ~}$ \\
Marguba B Track & $\mathbf{F 5 , F 1 5 , ~ F 1 8 . ~}$ \\
Marguba A Track & $\mathbf{F 1 , ~ F 2 , ~ F 1 3 , ~ F 1 6 . ~}$ \\
Ajaku Buffer Zone & $\mathbf{F 6 , F 7 , ~ F 8 , ~ F 1 2 . ~}$ \\
\end{tabular}

Table 4:Vegetation Assessment of Habitat used for feeding by Baboon around point of feacal collection

\begin{tabular}{|c|c|c|}
\hline Sample & Tree & Numbers of Family \\
\hline Plot & Species & Composition \\
\hline$F 1$ & 5 & 5 \\
\hline$F 2$ & 5 & 4 \\
\hline$F 3$ & 5 & 5 \\
\hline$F 4$ & 6 & 5 \\
\hline F5 & 6 & 4 \\
\hline F6 & 5 & 3 \\
\hline$F 7$ & 6 & 5 \\
\hline$F 8$ & 6 & 5 \\
\hline F9 & 5 & 5 \\
\hline$F 10$ & 4 & 4 \\
\hline$F 11$ & 5 & 2 \\
\hline$F 12$ & 6 & 4 \\
\hline$F 13$ & 5 & 4 \\
\hline$F 14$ & 5 & 2 \\
\hline$F 15$ & 5 & 3 \\
\hline F16 & 5 & 4 \\
\hline$F 17$ & 5 & 2 \\
\hline F18 & 6 & 3 \\
\hline
\end{tabular}


International Journal of Engineering Applied Sciences and Technology, 2020

Vol. 4, Issue 9, ISSN No. 2455-2143, Pages 299-323

Published Online January 2020 in IJEAST (http://www.ijeast.com)

Table 5:Seed species composition voided by Baboon

\begin{tabular}{|c|c|c|c|c|c|c|c|c|c|c|c|c|c|c|c|c|c|c|c|}
\hline Tree specie & F1 & F2 & F3 & F4 & F5 & F6 & F7 & F8 & F9 & F10 & F11 & F12 & F13 & F14 & F15 & F16 & F17 & F18 & Total \\
\hline Blighia sapida & & 2 & 2 & 2 & & & & & & 2 & 2 & & & 2 & & & $\mathbf{1}$ & & 13 \\
\hline Vitellaria paradoxa & & 1 & 2 & & & 2 & & & & 4 & 2 & & 2 & & & & & & 13 \\
\hline Citrus pomelo & & & & & & & & & 4 & & & 6 & & & & & & & 10 \\
\hline Piliostigma thonningii & 3 & & 3 & & & & & & 2 & & & & & 2 & 3 & & 3 & & 16 \\
\hline Parkia biglobosa & 2 & & & & 2 & & 2 & 2 & & & & & & & & 2 & & & 10 \\
\hline Sarcocephalus latifolius & & & & & & 4 & & & & 1 & & & 3 & & & 4 & & 2 & 14 \\
\hline Daterium macrocarpum & & & & $\mathbf{1}$ & & 1 & 1 & 1 & & & & & & & & & & & 4 \\
\hline Total & 5 & 5 & 7 & 3 & 2 & 7 & 5 & 5 & 6 & 7 & 4 & 6 & 5 & 4 & 3 & 6 & 4 & 2 & 86 \\
\hline
\end{tabular}




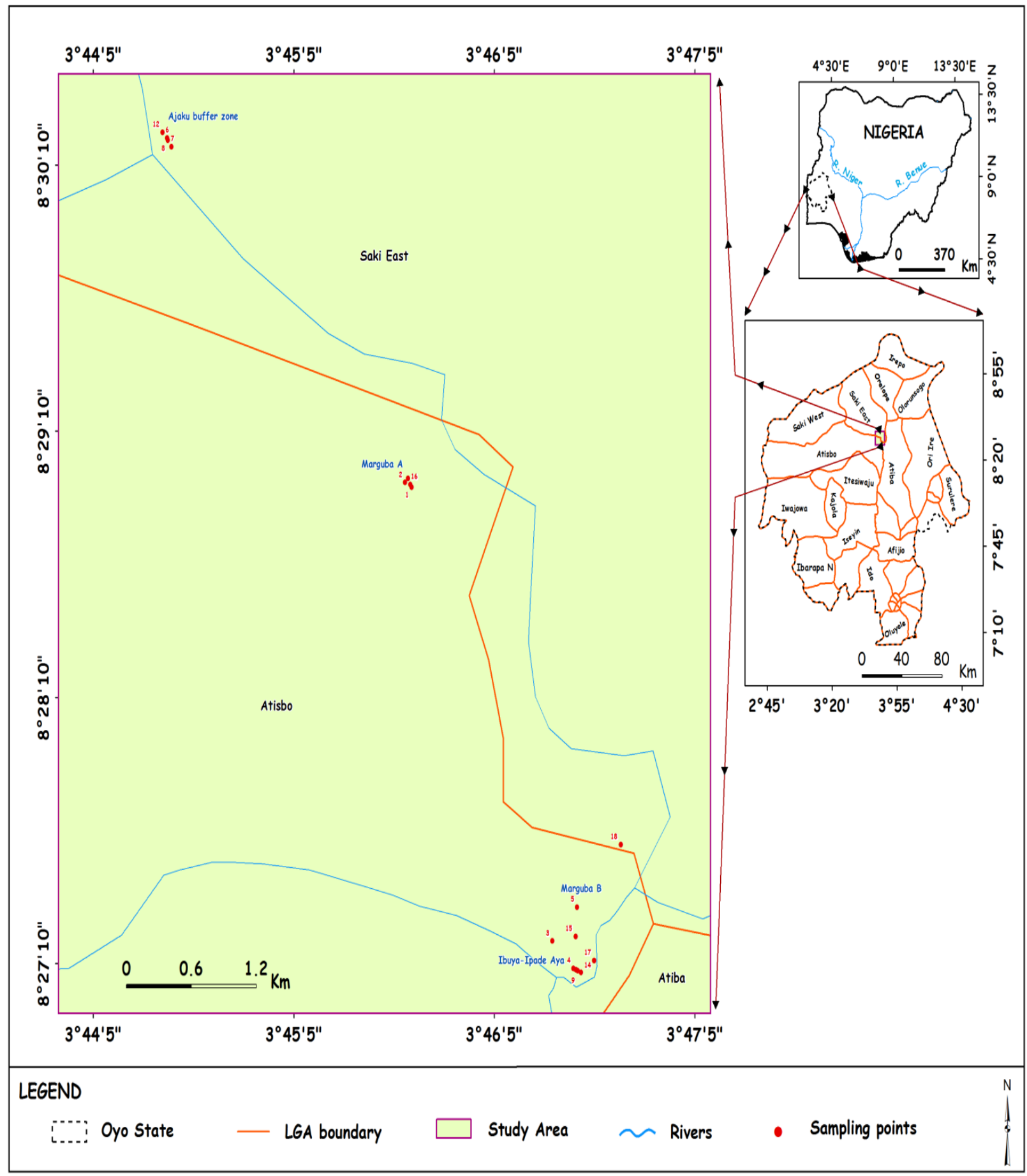

Figure 2: Map showing the point of feacal extraction (habitat utilization) in the park. 


\section{Weight of Baboon Feacal Seeds and Seed from Forest Research Institute of Nigeria (FRIN)}

Weight of Baboon Feaces and Seed Constituent Appendix 3 shows the individual weight of each seed specie extracted from the various fecal sample collected. Due to the tiny nature of Sarcocepalus latifolius seed, its seeds were not measured individually but the total seed extracted in each fecal dropping collected was measured together and has a range of $0.02 \mathrm{~g}-0.03 \mathrm{~g}$ which shows to have the lowest weight. Other seeds were measured individually (Table 6).

\section{Weight of Sample Seeds Collected from Forest Research Institute of Nigeria (FRIN)}

Shown in Table 7 is the weight $(\mathrm{g})$ of seed species collected from the Forest Research Institute of Nigeria (FRIN) as a unit of control to check for variation and for similarities with Baboon feacal seed extract. The weight of seeds extracted from the fecal sample of all species shows a reduction compared the fresh seeds obtained from FRIN Parkia biglobosa has the highest seed weight, while Sacrocephalus latifolius has the lowest weight (Table 7).

\section{Regeneration Capacity of Baboon feacal seeds}

Table 8 shows the number of seeds that had visible sign of growth within the two months of planting in relation to the number of seed species extracted in each feacal sample collected. It also shows the approximated percentage of germinated seeds in relation to the number of extracted seeds.

Feacal sample (F1) had the highest percentage of seed germination $(80 \%)$, while F18 showed to have $0 \%$ viability (i.e. no visible growth). All fecal samples extracted within the Marguba B (F5, F15, F18) track, also had $0 \%$ seed germination (i.e. No visible growth from all seeds extracted). Likewise, Vitellaria paradoxa showed no visible sign of growth in all the seeds extracted.
Table 6: Weight of Baboon Feaces and Seeds

\begin{tabular}{lll}
\hline Sample & $\begin{array}{l}\text { Feacal } \\
\text { Weight } \\
\text { Before Seed } \\
\text { Extraction }\end{array}$ & $\begin{array}{l}\text { Total Weight of } \\
\text { Seeds }\end{array}$ \\
& $\mathbf{2 5 6 . 9}$ & $\mathbf{6 . 9}$ \\
\hline F1 & $\mathbf{2 0 6}$ & $\mathbf{5 . 4}$ \\
F2 & $\mathbf{2 2 6 . 2}$ & $\mathbf{5 . 8}$ \\
F3 & $\mathbf{2 2 6}$ & $\mathbf{5 . 3}$ \\
F4 & $\mathbf{1 7 5}$ & $\mathbf{4 . 8}$ \\
F5 & $\mathbf{2 3 5 . 4 3}$ & $\mathbf{4 . 6 3}$ \\
F6 & $\mathbf{2 0 8 . 6}$ & $\mathbf{8 . 1}$ \\
F7 & $\mathbf{1 9 6 . 7}$ & $\mathbf{7 . 8}$ \\
F8 & $\mathbf{2 0 7 . 4}$ & $\mathbf{2 . 6}$ \\
F9 & $\mathbf{2 8 3 . 3}$ & $\mathbf{1 2 . 5}$ \\
F10 & $\mathbf{1 7 7 . 7}$ & $\mathbf{8 . 5}$ \\
F11 & $\mathbf{1 8 0 . 3}$ & $\mathbf{2 . 6}$ \\
F12 & $\mathbf{2 6 5 . 2 3}$ & $\mathbf{4 . 7 3}$ \\
F13 & $\mathbf{2 4 0 . 1}$ & $\mathbf{4 . 8}$ \\
F14 & $\mathbf{2 0 1 . 2}$ & $\mathbf{1 . 4}$ \\
F15 & $\mathbf{2 5 2 . 7 3}$ & $\mathbf{5 . 1 3}$ \\
F16 & $\mathbf{1 6 6 . 3}$ & $\mathbf{3 . 5}$ \\
F17 & $\mathbf{1 6 0 . 4 2}$ & $\mathbf{0 . 0 2}$ \\
F18 & & \\
\hline
\end{tabular}

Table 7: Weight (g) of Seed Collected from Forest Research Institute of Nigeria (FRIN), Before Planting

\begin{tabular}{ll}
\hline Seed Species & $\begin{array}{l}\text { Weight of seed } \\
\text { species }\end{array}$ \\
\hline Blighia sapida & $2.490 \pm 0.014^{\mathrm{f}}$ \\
\hline Vitex doniana & $0.980 \pm 0.028^{\mathrm{d}}$ \\
\hline Vitellaria paradoxa & $2.985 \pm 0.021^{\mathrm{h}}$ \\
\hline Citrus pomelo & $0.615 \pm 0.021^{\mathrm{b}}$ \\
\hline Piliostigma thonningii & $0.810 \pm 0.014^{\mathrm{c}}$ \\
\hline Parkia biglobosa & $2.815 \pm 0.021^{\mathrm{g}}$ \\
\hline Sarcocephalus latifolius & $0.015 \pm 0.007^{\mathrm{a}}$ \\
\hline Detarium macrocarpum & $1.685 \pm 0.021^{\mathrm{e}}$ \\
\hline
\end{tabular}

The mean value in the same column with different superscripts are significant different $(\mathrm{p}<0.05)$ 
International Journal of Engineering Applied Sciences and Technology, 2020

Vol. 4, Issue 9, ISSN No. 2455-2143, Pages 299-323

Published Online January 2020 in IJEAST (http://www.ijeast.com)

Table 8: Seed Germination and Percentage Germination

\begin{tabular}{|c|c|c|c|c|c|c|c|c|c|c|c|c|c|c|c|c|c|c|c|}
\hline \multirow[t]{2}{*}{$S$} & \multicolumn{2}{|c|}{$B S$} & \multicolumn{2}{|c|}{$V d$} & \multicolumn{2}{|c|}{$V p$} & \multicolumn{2}{|l|}{$C p$} & \multicolumn{2}{|c|}{$P t$} & \multicolumn{2}{|c|}{$P b$} & \multicolumn{2}{|l|}{$S l$} & \multicolumn{2}{|c|}{$D m$} & \multicolumn{2}{|c|}{ Total } & \multirow[t]{2}{*}{ \% Germination } \\
\hline & $E$ & $G$ & $E$ & $G$ & $E$ & $G$ & $E$ & $G$ & $E$ & $G$ & $E$ & $G$ & $E$ & $G$ & $E$ & $G$ & $E$ & $G$ & \\
\hline$F 1$ & & & & & & & & & 3 & 2 & 2 & 2 & & & & & 5 & 4 & $80 \%$ \\
\hline$F 2$ & 2 & 1 & 2 & 1 & 1 & 0 & & & & & & & & & & & 5 & 2 & $40 \%$ \\
\hline$F 3$ & 2 & 1 & & & 2 & 0 & & & 3 & 2 & & & & & & & 7 & 3 & $43 \%$ \\
\hline$F 4$ & 2 & 1 & & & & & & & & & & & & & 1 & 1 & 3 & 2 & $67 \%$ \\
\hline$F 5$ & & & & & & & & & & & 2 & 0 & & & & & 2 & 0 & $0 \%$ \\
\hline$F 6$ & & & & & 2 & 0 & & & & & & & 4 & 2 & 1 & 1 & 7 & 3 & $43 \%$ \\
\hline$F^{7}$ & & & 2 & 1 & & & & & & & 2 & 1 & & & 1 & 0 & 5 & 2 & $40 \%$ \\
\hline$F 8$ & & & 2 & 1 & & & & & & & 2 & 1 & & & 1 & 0 & 5 & 2 & $40 \%$ \\
\hline$F 9$ & & & & & & & 4 & 2 & 2 & 1 & & & & & & & 6 & 3 & $50 \%$ \\
\hline
\end{tabular}


International Journal of Engineering Applied Sciences and Technology, 2020

Vol. 4, Issue 9, ISSN No. 2455-2143, Pages 299-323

Published Online January 2020 in IJEAST (http://www.ijeast.com) 
Days Before Emergence of Planted Seeds from Feacal Sample in Relation to Seeds from Forest Research Institute of Nigeria (FRIN), Within Two Months

Table 9 shows the days before visible sign of growth was observed in germinated seeds after sowing within Two months. Feacal sample having more than a seed of the same species that germinated, were both recorded in the same box. Fecal collection whose species of seed shows no sign of growth in any of its seed planted was recorded as "No Visible growth". Table 10 shows the days before emergence of the seed species collected from FRIN after appropriate treatment and sown for a period of Two (2) months.

Height of Plants Grown from Feacal Sample Seeds in Relation to Heights from Seed Collected from Forest Research Institute of Nigeria (FRIN), After Two Months of Planting.

Table 9: Days of Seedling Emergence of Seeds Collected from Baboon Feaces

\begin{tabular}{|c|c|c|}
\hline Fecal sample & Seeds & $\begin{array}{l}\text { Days of } \\
\text { Emergence }\end{array}$ \\
\hline \multirow[t]{2}{*}{ F1 } & $\begin{array}{l}\text { Piliostigma } \\
\text { thonningii }\end{array}$ & 14 and 16 \\
\hline & Parkia biglobosa & 15 and 16 \\
\hline \multirow[t]{3}{*}{$\mathrm{F} 2$} & Blighia sapida & 15 \\
\hline & Vitex doniana & 14 \\
\hline & $\begin{array}{l}\text { Vitellaria } \\
\text { paradoxa }\end{array}$ & $\begin{array}{l}\text { No Visible } \\
\text { growth }\end{array}$ \\
\hline \multirow[t]{3}{*}{ F3 } & Blighia sapida & 16 \\
\hline & $\begin{array}{l}\text { Vitellaria } \\
\text { paradoxa }\end{array}$ & $\begin{array}{l}\text { No Visible } \\
\text { growth }\end{array}$ \\
\hline & $\begin{array}{l}\text { Piliostigma } \\
\text { thonningii }\end{array}$ & 16 and 20 \\
\hline \multirow[t]{2}{*}{$\mathrm{F} 4$} & Blighia sapida & 16 \\
\hline & $\begin{array}{l}\text { Detarium } \\
\text { macrocarpum }\end{array}$ & 8 \\
\hline F5 & Parkia biglobosa & $\begin{array}{l}\text { No Visible } \\
\text { growth }\end{array}$ \\
\hline \multirow[t]{2}{*}{ F6 } & $\begin{array}{l}\text { Vitellaria } \\
\text { paradoxa }\end{array}$ & $\begin{array}{l}\text { No Visible } \\
\text { growth }\end{array}$ \\
\hline & $\begin{array}{l}\text { Sarcocephalus } \\
\text { latifolius }\end{array}$ & 21 and 24 \\
\hline
\end{tabular}

The growth rate of the all the viable seeds that emerged after nurturing for a period of two months was observed and recorded. Detarium macrocarpum showed to exhibit the highest height of $17 \mathrm{~cm}$ which was present in seed extracted from fecal sample F4, while Parkia biglobosa, showed to have the lowest height of all emerged seedlings of tree, with a height range of $5.6 \mathrm{~cm}-8 \mathrm{~cm}$ (Table 11). Table 12 shows the growth rate/ Plant height of seedling from FRIN after Two (2) months of sowing.

\section{Species Composition of Plant Resources around Defecated Site}

Twenty-eight (28) species of trees were identified in total, around the eighteen (18) fecal samples collected. Vitellaria paradoxa and Piliostigma thonningii was Vitellaria paradoxa and Piliostigma thonningii was the most abundant tree species, found to have habitat presence within nine (9) out of the eighteen (18) feacal extract site (Table 13).

\begin{tabular}{|c|c|c|}
\hline & $\begin{array}{l}\text { Detarium } \\
\text { macrocarpum }\end{array}$ & 7 \\
\hline \multirow[t]{3}{*}{ F7 } & Vitex doniana & 14 \\
\hline & Parkia biglobosa & 18 \\
\hline & $\begin{array}{l}\text { Detarium } \\
\text { macrocarpum }\end{array}$ & $\begin{array}{l}\text { No Visible } \\
\text { growth }\end{array}$ \\
\hline \multirow[t]{3}{*}{ F8 } & Vitex doniana & 19 \\
\hline & Parkia biglobosa & 15 \\
\hline & $\begin{array}{l}\text { Detarium } \\
\text { macrocarpum }\end{array}$ & $\begin{array}{l}\text { No Visible } \\
\text { growth }\end{array}$ \\
\hline \multirow[t]{2}{*}{ F9 } & Citrus pomelo & 8 and 10 \\
\hline & $\begin{array}{l}\text { Piliostigma } \\
\text { thonningii }\end{array}$ & 15 \\
\hline \multirow[t]{3}{*}{ F10 } & Blighia sapida & $\begin{array}{l}\text { No Visible } \\
\text { growth }\end{array}$ \\
\hline & $\begin{array}{l}\text { Vitellaria } \\
\text { paradoxa }\end{array}$ & $\begin{array}{l}\text { No Visible } \\
\text { growth }\end{array}$ \\
\hline & $\begin{array}{l}\text { Sarcocephalus } \\
\text { latifolius }\end{array}$ & $\begin{array}{l}\text { No Visible } \\
\text { growth }\end{array}$ \\
\hline \multirow[t]{2}{*}{ F11 } & Blighia sapida & 16 \\
\hline & $\begin{array}{l}\text { Vitellaria } \\
\text { paradoxa }\end{array}$ & $\begin{array}{l}\text { No Visible } \\
\text { growth }\end{array}$ \\
\hline F12 & Citrus pomelo & $9 ; 12$ and 14 \\
\hline F13 & $\begin{array}{l}\text { Vitellaria } \\
\text { paradoxa }\end{array}$ & $\begin{array}{l}\text { No Visible } \\
\text { growth }\end{array}$ \\
\hline
\end{tabular}


International Journal of Engineering Applied Sciences and Technology, 2020

Vol. 4, Issue 9, ISSN No. 2455-2143, Pages 299-323

Published Online January 2020 in IJEAST (http://www.ijeast.com)

\begin{tabular}{l|l|l}
\hline \multirow{2}{*}{ F14 } & $\begin{array}{l}\text { Sarcocephalus } \\
\text { latifolius }\end{array}$ & 24 \\
& Blighia sapida & $\begin{array}{l}\text { No Visible } \\
\text { growth }\end{array}$ \\
\cline { 2 - 3 } & $\begin{array}{l}\text { Piliostigma } \\
\text { thonningii }\end{array}$ & 14 \\
\hline F15 & $\begin{array}{l}\text { Piliostigma } \\
\text { thonningii }\end{array}$ & $\begin{array}{l}\text { No Visible } \\
\text { growth }\end{array}$ \\
\hline F16 & Parkia biglobosa & 14 \\
\hline
\end{tabular}

\begin{tabular}{l|l|l}
\hline & $\begin{array}{l}\text { Sarcocephalus } \\
\text { latifolius }\end{array}$ & 21 and 23 \\
\hline F17 & Blighia sapida & 15 \\
\cline { 2 - 3 } & $\begin{array}{l}\text { Piliostigma } \\
\text { thonningii }\end{array}$ & 18 \\
\hline F18 & $\begin{array}{l}\text { Sarcocephalus } \\
\text { latifolius }\end{array}$ & $\begin{array}{l}\text { No Visible } \\
\text { growth }\end{array}$ \\
\hline
\end{tabular}

Table 10: $\quad$ Days Before Seedling Emergence of Seeds Collected from Forest Research Institute of Nigeria (FRIN).

\begin{tabular}{cccccccc}
\hline $\begin{array}{l}\text { Blighia } \\
\text { sapida }\end{array}$ & Vitex doniana & $\begin{array}{l}\text { Vitellaria } \\
\text { paradoxa }\end{array}$ & $\begin{array}{l}\text { Citrus } \\
\text { pomelo }\end{array}$ & $\begin{array}{l}\text { Piliostigma } \\
\text { thonningii }\end{array}$ & $\begin{array}{l}\text { Parkia } \\
\text { biglobosa }\end{array}$ & $\begin{array}{l}\text { Sarcocephalus } \\
\text { latifolius }\end{array}$ & $\begin{array}{l}\text { Detarium } \\
\text { macrocarpum }\end{array}$ \\
\hline 16 days & $25-26$ days & $\begin{array}{c}\text { No Visible } \\
\text { Growth }\end{array}$ & 7 days & 10-11 days & $8-10$ days & 14 days & 9 days
\end{tabular}


Table 11: $\quad$ Feacal Seeds Plant Height After Two (2) Months of Planting

\begin{tabular}{|c|c|c|}
\hline $\begin{array}{l}\text { Fecal } \\
\text { sample }\end{array}$ & Seeds & $\begin{array}{l}\text { Plant } \\
\text { Height } \\
(\mathrm{CM})\end{array}$ \\
\hline \multirow[t]{2}{*}{ F1 } & $\begin{array}{l}\text { Piliostigma } \\
\text { thonningii }\end{array}$ & 9.3 and 8.5 \\
\hline & Parkia biglobosa & 6 and 5.6 \\
\hline \multirow[t]{3}{*}{$\mathrm{F} 2$} & Blighia sapida & 14.3 \\
\hline & Vitex doniana & 10.8 \\
\hline & $\begin{array}{l}\text { Vitellaria } \\
\text { paradoxa }\end{array}$ & $\begin{array}{l}\text { No Visible } \\
\text { growth }\end{array}$ \\
\hline \multirow[t]{3}{*}{ F3 } & Blighia sapida & 14 \\
\hline & $\begin{array}{l}\text { Vitellaria } \\
\text { paradoxa }\end{array}$ & $\begin{array}{l}\text { No Visible } \\
\text { growth }\end{array}$ \\
\hline & $\begin{array}{l}\text { Piliostigma } \\
\text { thonningii }\end{array}$ & 9 and 8.6 \\
\hline \multirow[t]{2}{*}{ F4 } & Blighia sapida & 13.8 \\
\hline & $\begin{array}{l}\text { Detarium } \\
\text { macrocarpum }\end{array}$ & 17 \\
\hline F5 & Parkia biglobosa & $\begin{array}{l}\text { No Visible } \\
\text { growth }\end{array}$ \\
\hline \multirow[t]{3}{*}{ F6 } & $\begin{array}{l}\text { Vitellaria } \\
\text { paradoxa }\end{array}$ & $\begin{array}{l}\text { No Visible } \\
\text { growth }\end{array}$ \\
\hline & $\begin{array}{l}\text { Sarcocephalus } \\
\text { latifolius }\end{array}$ & 12 and 10 \\
\hline & $\begin{array}{l}\text { Detarium } \\
\text { macrocarpum }\end{array}$ & 16.4 \\
\hline \multirow[t]{3}{*}{ F7 } & Vitex doniana & 11 \\
\hline & Parkia biglobosa & 6 \\
\hline & $\begin{array}{l}\text { Detarium } \\
\text { macrocarpum }\end{array}$ & $\begin{array}{l}\text { No Visible } \\
\text { growth }\end{array}$ \\
\hline \multirow[t]{2}{*}{ F8 } & Vitex doniana & 10.9 \\
\hline & Parkia biglobosa & 6.5 \\
\hline
\end{tabular}

\begin{tabular}{|c|c|c|}
\hline & $\begin{array}{l}\text { Detarium } \\
\text { macrocarpum }\end{array}$ & $\begin{array}{l}\text { No Visible } \\
\text { growth }\end{array}$ \\
\hline \multirow[t]{2}{*}{ F9 } & Citrus pomelo & $8 ; 6$ \\
\hline & $\begin{array}{l}\text { Piliostigma } \\
\text { thonningii }\end{array}$ & 9 \\
\hline \multirow[t]{3}{*}{ F10 } & Blighia sapida & $\begin{array}{l}\text { No Visible } \\
\text { growth }\end{array}$ \\
\hline & $\begin{array}{l}\text { Vitellaria } \\
\text { paradoxa }\end{array}$ & $\begin{array}{l}\text { No Visible } \\
\text { growth }\end{array}$ \\
\hline & $\begin{array}{l}\text { Sarcocephalus } \\
\text { latifolius }\end{array}$ & $\begin{array}{l}\text { No Visible } \\
\text { growth }\end{array}$ \\
\hline \multirow[t]{2}{*}{ F11 } & Blighia sapida & 13 \\
\hline & $\begin{array}{l}\text { Vitellaria } \\
\text { paradoxa }\end{array}$ & $\begin{array}{l}\text { No Visible } \\
\text { growth }\end{array}$ \\
\hline F12 & Citrus pomelo & $\begin{array}{l}7.2 ; 7 \text { and } \\
6.2\end{array}$ \\
\hline \multirow[t]{2}{*}{ F13 } & $\begin{array}{l}\text { Vitellaria } \\
\text { paradoxa }\end{array}$ & $\begin{array}{l}\text { No Visible } \\
\text { growth }\end{array}$ \\
\hline & $\begin{array}{l}\text { Sarcocephalus } \\
\text { latifolius }\end{array}$ & 12 \\
\hline \multirow[t]{2}{*}{ F14 } & Blighia sapida & $\begin{array}{l}\text { No Visible } \\
\text { growth }\end{array}$ \\
\hline & $\begin{array}{l}\text { Piliostigma } \\
\text { thonningii }\end{array}$ & 9.1 \\
\hline F15 & $\begin{array}{l}\text { Piliostigma } \\
\text { thonningii }\end{array}$ & $\begin{array}{l}\text { No Visible } \\
\text { growth }\end{array}$ \\
\hline \multirow[t]{2}{*}{ F16 } & Parkia biglobosa & 7 \\
\hline & $\begin{array}{l}\text { Sarcocephalus } \\
\text { latifolius }\end{array}$ & 13 and 10 \\
\hline \multirow[t]{2}{*}{ F17 } & Blighia sapida & 14 \\
\hline & $\begin{array}{l}\text { Piliostigma } \\
\text { thonningii }\end{array}$ & 8 \\
\hline F18 & $\begin{array}{l}\text { Sarcocephalus } \\
\text { latifolius }\end{array}$ & $\begin{array}{l}\text { No Visible } \\
\text { growth }\end{array}$ \\
\hline
\end{tabular}


International Journal of Engineering Applied Sciences and Technology, 2020

Vol. 4, Issue 9, ISSN No. 2455-2143, Pages 299-323

Published Online January 2020 in IJEAST (http://www.ijeast.com)

Table 12: Plant Height of Seed Collected from Forest Research Institute of Nigeria (FRIN), After Two

Months of Sowing

\begin{tabular}{clllllll}
\hline $\begin{array}{l}\text { Blighia } \\
\text { sapida }\end{array}$ & $\begin{array}{l}\text { Vitex } \\
\text { doniana }\end{array}$ & $\begin{array}{l}\text { Vitellaria } \\
\text { paradoxa }\end{array}$ & $\begin{array}{l}\text { Citrus } \\
\text { pomelo }\end{array}$ & $\begin{array}{l}\text { Piliostigma } \\
\text { thonningii }\end{array}$ & $\begin{array}{l}\text { Parkia } \\
\text { biglobosa }\end{array}$ & $\begin{array}{l}\text { Sarcocephalus } \\
\text { latifolius }\end{array}$ & $\begin{array}{l}\text { Detarium } \\
\text { macrocarpum }\end{array}$ \\
\hline $14 c m$ & $4-4.1 c m$ & $\begin{array}{c}\text { No Visible } \\
\text { Growth }\end{array}$ & $10 \mathrm{~cm}$ & $\mathbf{1 0 . 8}-11 \mathrm{~cm}$ & $\mathbf{9 . 5 - 1 0 \mathrm { cm }}$ & $16 \mathrm{~cm}$ & $15 \mathrm{~cm}$
\end{tabular}


International Journal of Engineering Applied Sciences and Technology, 2020

Vol. 4, Issue 9, ISSN No. 2455-2143, Pages 299-323

Published Online January 2020 in IJEAST (http://www.ijeast.com)

Table 13: $\quad$ Tree species abundance around sampled site

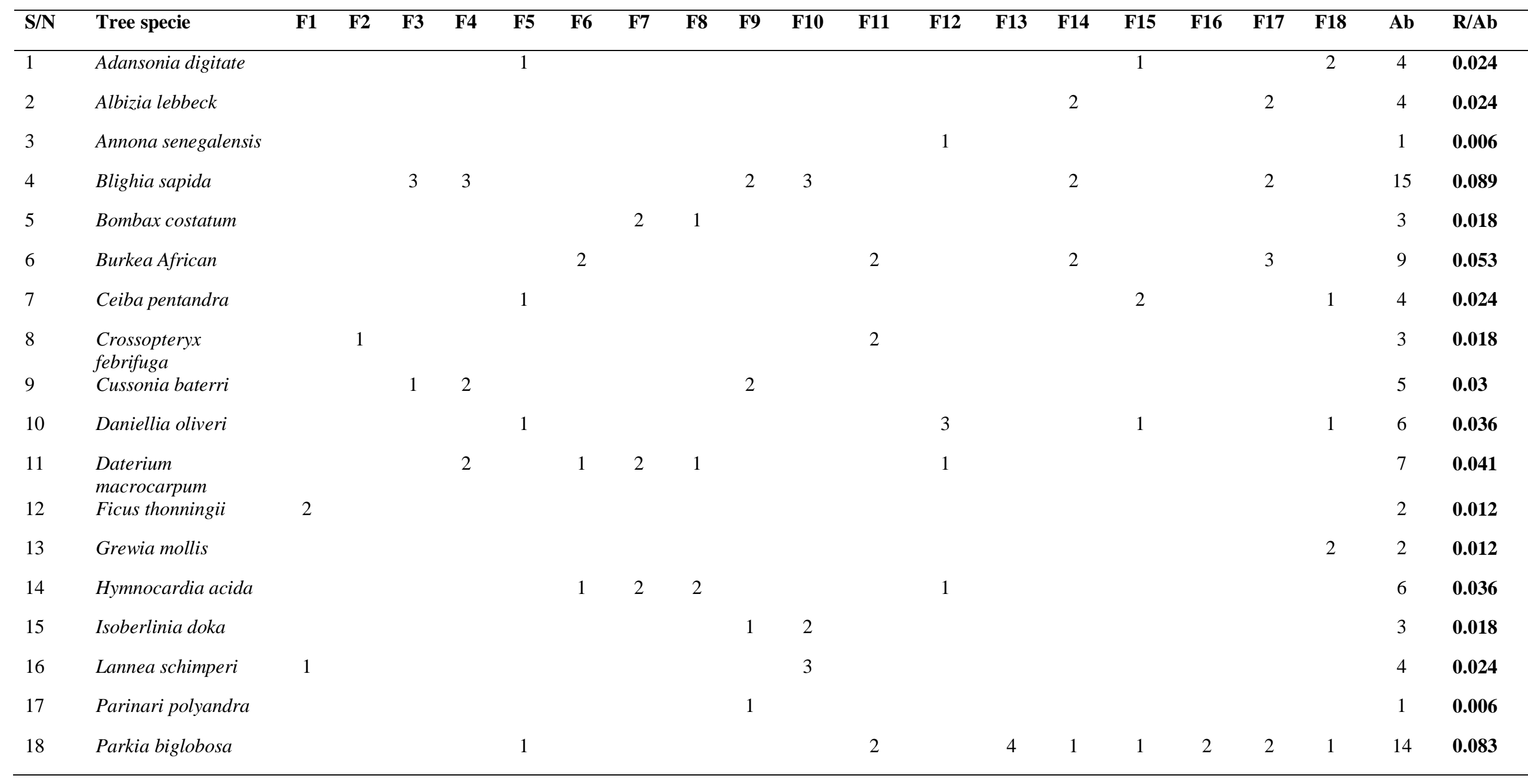


International Journal of Engineering Applied Sciences and Technology, 2020

Vol. 4, Issue 9, ISSN No. 2455-2143, Pages 299-323

Published Online January 2020 in IJEAST (http://www.ijeast.com)

\begin{tabular}{|c|c|c|c|c|c|c|c|c|c|c|c|c|c|c|c|c|c|c|c|c|c|}
\hline 19 & $\begin{array}{l}\text { Piliostigma } \\
\text { thonningii }\end{array}$ & 3 & 2 & 2 & 1 & & & & & & & 2 & & 1 & 2 & & 2 & 1 & & 16 & 0.095 \\
\hline 20 & $\begin{array}{l}\text { Pterocarpus } \\
\text { erinaceus }\end{array}$ & & & & & & & & & & & 2 & & & & & & & & 2 & 0.012 \\
\hline 21 & $\begin{array}{l}\text { Sarcocephalus } \\
\text { latifolius }\end{array}$ & 2 & 4 & & & & & 1 & 2 & & & & & 2 & & & 2 & & & 13 & $\mathbf{0 . 0 7 7}$ \\
\hline 22 & $\begin{array}{l}\text { Securidaca } \\
\text { longipedunculata }\end{array}$ & & & & & & & & & & & & & & & 2 & & & & 2 & 0.012 \\
\hline 23 & Sido cidrellia & & & & & & 2 & 1 & 2 & & & & 1 & & & & & & & 6 & 0.036 \\
\hline 24 & $\begin{array}{l}\text { Sterospermum } \\
\text { kunthianum }\end{array}$ & & & & & 1 & & & & & & & & & & & & & 1 & 2 & 0.012 \\
\hline 25 & Strychnos spinosa & & & & & & & & & & & & & 2 & & & 2 & & & 4 & 0.024 \\
\hline 26 & Terminalia glycoscen & & & 2 & 2 & & & & & & & & & & & & & & & 4 & 0.024 \\
\hline 27 & Vitellaria paradoxa & 2 & 1 & 2 & 1 & 2 & & & & 3 & 2 & & & 1 & & & 2 & & & 16 & 0.095 \\
\hline 28 & Vitex doniana & & 2 & & & & 3 & 2 & 2 & & & & 2 & & & & & & & 11 & 0.065 \\
\hline & Total & 10 & 10 & 10 & 11 & 7 & 9 & 10 & 10 & 9 & 10 & 10 & 9 & 10 & 9 & 7 & 10 & 10 & 8 & 169 & 1 \\
\hline
\end{tabular}

*Ab- Abundance, $\mathrm{R} / \mathrm{Ab}$ - Relative Abundance.

\section{DISCUSSION}

There was a low rate of baboon sighted within the park, which was suggested to be caused by the raining season in which this research was carried out, which allows for abundant food material and water in their hideout, which was supported by Byrne (1981), that Baboon population increases in wet season, when visibility is reduced, and food are more abundant within their hideout. The findings from the study revealed that Baboon's presence was mostly felt around the buffer zone, denoting its range of habitat which could be due to the nearness of the buffer zone to farms where food crops and fruits could be found and also the diverse and dense population of tree species in this zone which serve as a source of nutrition for this primate. This agrees with the assertion that wild animals are more distributed 


\section{International Journal of Engineering Applied Sciences and Technology, 2020 \\ Vol. 4, Issue 9, ISSN No. 2455-2143, Pages 299-323 \\ Published Online January 2020 in IJEAST (http://www.ijeast.com)}

in areas with abundant food, water space and mates, and also agrees to the view of Newton (1998) and Benton et al., (2003) that food abundance influences the distribution and size of wildlife populations. Furthermore, this manifested in the number of fecal sample extracted around the buffer zone, with transects around the buffer zone (Marguba A, Ajaku Buffer Zone and Ibuya-Ipade Aya Track) having the highest number of fecal extract, which is due to the baboons flair for nearby farm for obtaining food substances and fruits, which corroborate the findings of Adetoro et al., (2011) who stated that that villagers reported $90 \%$ of maize destruction and locust bean destruction in their farms to be from Baboon.

Feacal extract within the same transect was found to exhibit similar surrounding vegetation within its 15 meters' radius. Citrus pomelo was not encountered during the course of this study in the park and in its surrounding, suggesting that baboon species obtain this fruit from surrounding farms. This would help greatly in introduction of new tree species or exotic species into the park region, thereby increasing the population of tree species and subsequently regeneration of the park.

It would be observed that seeds extracted from all the feacal samples show reduction in weight compared to the control seed (seeds collected from FRIN), which could be evidence of heat action and digestive enzymes on the seed supporting Kleyheeg, (2015) that the diversity of digestive processes and variable intensity of digestive forces between and within individuals are likely to greatly affect seed gut passage weight and survival, but very little is known about their interactions with seed traits, which could also support the exception seen in seeds of pomelo which shows to have some of its seeds not changing in weight with the control seed.

The growth emergence rate of Vitex doniana which presents a combination of physical and physiological dormancy, based on classification by Baskin and Baskin (2004) was increased compared to the control. There was early growth of 14-19 days compared to the control which took 25-26 days before visible sign of seedling growth was noticed This shows that the passage of seed through the gut of baboon serves to affect the dormancy of Vitex doniana. The growth emergence rate of Citrus pomelo was reduced having a range of 8-14 days, compared to the 7 days found in the control. The emergence rate of Piliostigma thonningii was also slowed down, having an emergence day range of 14- 20 days compared to the 10-11 days observed in the control. This was also seen in Parkia biglobosa having an emergence date of 15-
18 days compared to 8-10 days of the control, which was also concurrent in Sacrocephalus latifolius, while Daterium macrocarpum whose seed also has hard coating, which prevents the seeds from easy germination when the condition for germination is available, showed a faster rate of emergence (7 - 8 days) as compared to 9 days of the control. This shows that movement of the seed through the gut of baboon is an effective method of softening hard coated seed of Daterium macrocarpum, thereby affecting its dormancy. The growth emergence rate of Blighia sapida was found almost constant with that of the control, which suggest that movement of the fruit in the gut of Baboon has little or no effect on the seed.

The growth rate of Blighia sapida extracted from the fecal sample and that obtained from FRIN (the control), shows a high rate of correlation, therefore suggesting that the movement of this fruit through the gut of Baboon has little or no effect on the seed.

\section{CONCLUSION}

The impact of baboon on habitat regeneration within the marguba range of old Oyo national park have been studied. The range of habitat composed of high occurrence of baboon has been identified; with the high ratio of baboon's fecal sample extracted in and within the buffer zone and also the high ratio of visual encounter of baboon within this zone, suggests for the invasion of this non-human primate into neighboring habitat and vegetation's. The most preferred fruits within the park was also observed through the amount of seed of the species obtained, as seeds of Blighia sapida, Piliostigma thonningii and Vitellaria paradoxa was found to have the highest seed count which shows the high intake of this fruits and consequently its preference, leading to the high rate of dispersal of these seeds, which suggests for the dominant nature of this tree species within the study area and park, which could therefore be said that baboons have a positive effect in the dispersal of seed species and regeneration of trees within the park.

The passage of fruits through the digestive system of baboon has shown a reduction in the size of the seed, though this reduction in size varies and has an effect in the germination success or viability rate of the seed, as seeds with lowest weight range in a specie enumeration shows no significant growth, thereby reducing the regenerating ability of seeds dispersed. Passage of hard coated seed through the gut of baboon has shown to slightly improve its germination but has not shown to be an effective method in breaking seed dormancy. It could also be concluded that Baboons mostly get their food resources within the park, with 


\section{International Journal of Engineering Applied Sciences and Technology, 2020 \\ Vol. 4, Issue 9, ISSN No. 2455-2143, Pages 299-323 \\ Published Online January 2020 in IJEAST (http://www.ijeast.com)}

Seven of the Eight species (87.5\%) feacal seeds extracted having tree species presence within the park after conducting habitat assessment around each feacal defecation site.

\section{ACKNOWLEDGEMENT}

We would want to thank the staffs of Old Oyo National park and Forest Research Institute of Nigeria for their support and assistance during the course of this research.

\section{REFERENCE}

[1] A. O. Adetoro, D. O. Oyeleye, and H. M. Ijeomah, Causes and impacts of conflicts on biodiversity management at the buffer zone of Old Oyo National Park, Oyo state, Nigeria. African research review journal, Vol. 5, No. 1, pp. 485-495, 2011.

[2] J. I. Amonum, R. T. Nyam, and S. Gbande, Effect of Pre-Treatments on Seed Germination

of Parkia Biglobosa (Benth). Journal of Research in Forestry, Wildlife \& Environment, Vol. 8, No. 4, pp. 80-85, 2016.

[3] A. Angelsen, E. F. K. Shitindi, and J. Aaarrestad, Why do farmers expand their land into forests? Theories and evidence from Tanzania. Environment and Development Economics, Vol. 4, pp. 313-31, 1999.

[4] J. Baille, C. Hilton-Taylor, and S. N. Stuart, 2004 IUCN Red List of Threatened Species: A Global Assessment. International Union for Conservation of Nature, Cambridge, UK, 2004.

[5] S. Barraclough, and K. B. Ghimire, Agricultural Expansion and Tropical Deforestation. Earthscan, 2000.

[6] J. M. Baskin, and C. C. Baskin, A classification system for seed dormancy. Seed Science

Research, Vol. 14, pp. 1-16, 2004.

[7] T. G. Benton, J. A. Vickery, and J. D. Wilson, Farmland biodiversity: is habitat heterogeneity the key? Trends Ecol. Evol, Vol, 18, pp. 182-188, 2003.

[8] R. W. Bryne, Distance Vocalizations of Guinea Baboons (Papio papio) in Senegal: An analysis of function. Jstor journal, Vol, 78, No, 3, pp. 283-313, 1981.

[9] H. M. Burkill, The useful plants of West Tropical Africa. 2nd Edition. Volume 4, Families

M-R. Royal Botanic Gardens, Kew, Richmond, United Kingdom, pp. 969, 1997.
[10] W. Burnham, Estimate of density line transect sampling of biological population. Wildlife/Monogr, Vol. 71, pp. 202, 1980.

[11] R. Butler. Mongabay rainforests country profiles . https://rainforests.mongabay.com/20nigeria.htm, 2014.

[12] J. R. Charter, Map of Ecological Zones of Nigerian Vegetation. Federal Surveys, Federal Department of Forestry Ibadan, Nigeria, 1970.

[13] J. H. Connell, Diversity in tropical rain forests and coral reefs. Science, Vol. 199, pp.1302-1310, 1978.

[14] R. S. Duncan, and C. A. Chapman, Seed dispersal and potential forest succession in abandoned agriculture in tropical Africa. Ecological Applications, Vol. 9, pp. 998-1008, 1999.

[15] A. Dunn, A manual of census techniques for surveying large mammals' in tropical rainforests. Unpublished report to WWF/UK, pp. 49-55, 1993.

[16] FAO, The State of Food Insecurity in the World. Rome, Italy: Food and Agriculture

Organization of the United Nations, 2005.

[17] K. Fern, Notes from Observation, Tasting etc. at a plant for future and on field trips, 2014,

Accessed 29 October 2019.

[18] F. Herzog, Z. Farah, and R. Amado, Composition and consumption of gathered wild fruits in the VBaoulé, Côte d'Ivoire. Ecology of Food and Nutrition, Vol. 32, pp. 181-196, 1994.

[19] D. Jean, and D. Pierre, A field guide to the large mammals of Africa. Collins St. James publication, London, pp. 342, 1990.

[20] R. W. J. Keay, An outline of Nigerian Vegetation. Government printer, Lagos, 1959.

[21] E. Kleyheeg, Seed dispersal `by a generalist duck: ingestion, digestion and transportation

by mallards (Anas platyrhynchos). PhD dissertation, Utrecht University, Utrecht, The Netherlands, 2015. Available

from: https://dspace.library.uu.nl/handle/1874/32059 $\underline{9}$.

[22] K. D. Koenig, Plants for a future, 1996-2012, 2012. Accessed 29 October 2019.

[23] A. M. Kouyaté, and P. van Damme, Detarium microcarpum Guill. \& Perr. In: G. H. Schmelzer, and A. Gurib-Fakim, (Editors), PROTA (Plant Resources of Tropical Africa / Ressources végétales de l'Afrique 


\section{International Journal of Engineering Applied Sciences and Technology, 2020 \\ Vol. 4, Issue 9, ISSN No. 2455-2143, Pages 299-323 \\ Published Online January 2020 in IJEAST (http://www.ijeast.com)}

tropicale), Wageningen, Netherlands, 2006. Accessed 29 October 2019.

[24] B. K. Kunz, and K. E. Linsenmair, The role of the olive baboon (Papio anubis, Cercopithecidae) as seed disperser in a savanna-forest mosaic of West Africa. Journal of Tropical Ecology, Vol. 24, pp. 235-246, 2008.

[25] D. Lemessa, Piliostigma thonningii (Schumach.) Milne-Redh. Record from PROTA4U. Brink, M. \& Achigan-Dako, E.G. (Editors). PROTA (Plant Resources of Tropical Africa / Ressources végétales de l'Afrique tropicale), Wageningen, Netherlands, 2010. http://www.prota4u.org/search.asp

[26] Y. Malhi, J. T. Roberts, R. A. Betts, T. J. Killeen, W. Li, and C. A. Nobre, Climate change, deforestation, and the fate of the Amazon. Science, Vol. 319, pp. 169-172, 2008.

[27] N. Myers, Tropical deforestation: rates and patterns. In: The Causes of Tropical of Tropical Deforestation. The economic and statistical analysis of factors giving rise to the loss of the tropical forest, $\mathrm{K}$. Brown, and D. Pearce, (editors), UCL Press, pp. $27-$ 40, 1994.

[28] I. Newton, Population limitation in birds. Academic Press, Oxford, UK, 1998.

[29] Nigeria Gallaria, Resource abundance of Old Oyo National Park Nigeria, 2017. www.nigeriagalleria.com.

[30] Nigeria National Park Service, "Old Oyo National Park", 2014. Retrieved 2014-11-24.

[31] A. Nikiema, and B. E. Umali, Vitellaria paradoxa C. F. Gaertn Record from PROTA4U, H. A. M. van der Vossen, and G. S. Mkamilo, (Editors). PROTA (Plant Resources of Tropical Africa/Ressources végétales de l'Afrique tropicale), Wageningen, Netherlands, 2007.

http://www.prota4u.org/search.asp.

[32] G. Nuñez-Iturri, O. Olsson. and H. F. Howe. Hunting reduces recruitment of primate dispersed trees in Amazonian Peru. Biological Conversation, Vol. 141, No. 6, pp. 1536-1546, 2008.

[33] A. C. M. Oliveira, and S. F. Ferrari, Seed dispersal by black-handed tamarins, Saguinus midas niger (Callitrichinae, Primates): implications for the regeneration of degraded forest habitats in eastern Amazonia. Journal of Tropical Ecology, Vol. 16, pp. 709-716, 2000.
[34] C. Sabogal, Regeneration of tropical dry forests in Central Arnenca, with examples from Nicaragua. Journal of Vegetation Science, Vol. 3, pp. 407-416, 1992.

[35] G. A. F. Seber, The estimation of animal abundance and relative parameters: $2^{\text {nd }}$ edition. Macmillan New York, pp. 332, 1982.

[36] United Nations, Environmental issues in Nigeria by Rhett Butler, 2012.

[37] G. C. Van Kooten, and E. H. Bulte, The economics of nature: managing biological assets. Blackwells, 2000.

[38] World-wide Fund for Nature. What impacts do human activities have on habitats and wildlife? (World-wide Fund for Nature, Switzerland), Fact sheet, 23 may 2017.

[39] J. M. Jr. Wunderle, The role of animal seed dispersal in accelerating native forest regeneration on degraded tropical lands. Forest Ecology and Management, Vol. 99, pp. 223-235, 1997. 
International Journal of Engineering Applied Sciences and Technology, 2020

Vol. 4, Issue 9, ISSN No. 2455-2143, Pages 299-323

Published Online January 2020 in IJEAST (http://www.ijeast.com)

\section{APPENDIX}

Appendix 1: Vegetation Assessment of Habitat used for feeding by

Baboons

SAMPLES SURROUNDING VEGETATIONS

F1 Sarcocephalus latifolius, Ficus thonningii, Piliostigma

thonningii, Lannea schimperi, Vitellaria paradoxa.

F2 Sacrocephalus latifolius, Crossopteryx febrifuga, Vitex doniana, Pilostigma thonningii, Vitellaria paradoxa.

Blighia sapida, Piliostigma thonningii, Vitelliaria paradoxa, Terminalia glycoscen, Cussonia baterii.

F4 Blighia sapida, Daterium macrocarpum, Vitellaria paradoxa, Cussonia baterii, Terminalia glycoscen, Piliostigma thonningii.

Parkia biglobosa, Ceiba pentandra, Vitellaria paradoxa, Sterospermum kunthianum, Adansonia digitata, Daniellia oliveri.

\section{Bombax}

costatum

Vitex

doniana,

Daterium macrocarpum, Sido cidrellia, Sacrocephalus latifolius, Hymnocardia acida.

Bombax costatum, Vitex doniana, Detarium macrocarpum, Sido cidrellia, Sacrocephalus latifolius, Hymnocardia acida.

Blighia sapida, Vitellaria paradoxa, Cussonia baterii, Isoberlinia doka, Parinari polyandra.

Blighia sapida, Vitellaria paradoxa, Lannea schimperi, Isoberlinia doka.

Crossopteryx febrifuga Burkea africanna, Parkia biglobosa, Pterocarpus erinaceus, Piliostigma thonningii.

Vitex doniana, Sido cidrellia, Daniellia oliveri, Annona senegalensis, Daterium macrocarpum,

Hymenocardia acida.
Sacrocephalus latifolius, Vitellaria paradoxa, Parkia biglobosa, Piliostigma thonningii, Strychnos spinosa.

Vitex doniana, Sido cidrellia, Burkea africana, Hymnocardia acida, Daterium macrocarpum. 
International Journal of Engineering Applied Sciences and Technology, 2020

Vol. 4, Issue 9, ISSN No. 2455-2143, Pages 299-323

Published Online January 2020 in IJEAST (http://www.ijeast.com)

F14 Blighia sapida, Burkea africana, Piliostigma thonningii, Albizia lebbeck, Parkia biglobosa.

F15

Parkia biglobosa, Ceiba pentandra, Adansonia digitanta, Securidaca longipedunculata, Daniellia oliveri.

F16 Strychnos spinosa, Parkia biglobosa, Sarcocephalus latifolius, Piliostigma thonningii, Vitellaria paradoxa.

F17 Blighia sapida, Piliostigma thonningii, Burkea africana, Albizia lebbeck, Parkia biglobosa.

F18 Parkia biglobosa, Ceiba pentandra, Sterospermum kunthianum, Grewia mollis, Daniella oliveri, Adansonia digitata.
Appendix 2: $\quad$ Family Name of Tree species composition around sampled site

\begin{tabular}{ll}
\hline Tree specie & Family Name \\
\hline Sarcocephalus latifolius & Rubiaceae \\
Ficus thonningii & Moraceae \\
Piliostigma thonningii & Fabaceae \\
Lannea schimperi & Anacardiaceae \\
Vitellaria paradoxa & Sapotaceae \\
Crossopteryx febrifuga & Rubiaceae \\
Vitex doniana & Lamiaceae \\
Blighia sapida & Sapindaceae \\
Terminalia glycoscen & Combretaceae \\
Cussonia baterri & Araliaceae \\
Daterium macrocarpum & Fabaceae \\
Parkia biglobosa & Fabaceae \\
Ceiba pentandra & Malvaceae \\
Sterospermum kunthianum & Bignoniaceae \\
Adansonia digitanta & Malvaceae \\
Daniellia oliveri & Fabaceae \\
Sido cidrellia & Fabaceae \\
Burkea African & Fabaceae \\
\hline
\end{tabular}


International Journal of Engineering Applied Sciences and Technology, 2020

Vol. 4, Issue 9, ISSN No. 2455-2143, Pages 299-323

Published Online January 2020 in IJEAST (http://www.ijeast.com)

Hymnocardia acida

Bombax costatum

Isoberlinia doka

Iperenia polyandra

Pterocarpus erinaceus

Annona senegalensis

Strychnos spinose

Albizia lebbeck

Securidaca longipedunculata

Grewia mollis
Phyllanthaceae

Malvaceae

Fabaceae

Chrysobalanaceae

Fabaceae

Annonaceae

Loganiaceae

Fabaceae

Polygalaceae

Malvaceae 
International Journal of Engineering Applied Sciences and Technology, 2020

Vol. 4, Issue 9, ISSN No. 2455-2143, Pages 299-323

Published Online January 2020 in IJEAST (http://www.ijeast.com)

Appendix 3: $\quad$ Weight (g) of Seeds Extracted from Baboon Fecal Dropping, Before Planting

\begin{tabular}{|c|c|c|c|c|c|c|c|c|}
\hline SAMPLES & $\begin{array}{l}\text { Blighia } \\
\text { sapida }\end{array}$ & $\begin{array}{l}\text { Vitex } \\
\text { donianan }\end{array}$ & $\begin{array}{l}\text { Vitellaria } \\
\text { paradoxa }\end{array}$ & $\begin{array}{l}\text { Citrus } \\
\text { pomelo }\end{array}$ & $\begin{array}{l}\text { Piliostigma } \\
\text { thonningii }\end{array}$ & $\begin{array}{l}\text { Parkia } \\
\text { biglobosa }\end{array}$ & $\begin{array}{l}\text { Sarcocep } \\
\text { halus } \\
\text { latifolius }\end{array}$ & $\begin{array}{l}\text { Daterium } \\
\text { macrocarpum }\end{array}$ \\
\hline$F 1$ & & & & & $0.6,0.5,0.6$ & $2.6,2.6$ & & \\
\hline$F 2$ & $2.2,1.9$ & $0.7,0.6$ & 2.6 & & & & & \\
\hline$F 3$ & $2.2,2.0$ & & & & $0.4,0.6,0.6$ & & & \\
\hline$F 4$ & $2.0,1.8$ & & & & & & & 1.5 \\
\hline F5 & & & & & & $2.4,2.4$ & & \\
\hline F6 & & & $2.4,2.2$ & & & & 0.03 & 1.5 \\
\hline F7 & & $0.8,0.7$ & & & & $2.6,2.5$ & & 1.5 \\
\hline$F 8$ & & $\begin{array}{l}0.8, \\
0.6\end{array}$ & & & & $2.4,2.5$ & & 1.5 \\
\hline F9 & & & & $\begin{array}{l}0.6,0.4, \\
0.2,0.5\end{array}$ & $0.4,0.5$ & & & \\
\hline$F 10$ & $1.9,2.0$ & & $\begin{array}{c}2.4,2.0,2.0 \\
2.2\end{array}$ & & & & & \\
\hline F11 & $2.1,2.0$ & & $2.0,2.4$ & & & & & \\
\hline$F 12$ & & & & $\begin{array}{l}0.5,0.5 \text {, } \\
0.6,0.2, \\
0.4,0.4\end{array}$ & & & & \\
\hline$F 13$ & & & $2.5,2.2$ & & & & 0.03 & \\
\hline F14 & $1.8,1.9$ & & & & $0.4,0.7$ & & & \\
\hline$F 15$ & & & & & $0.4,0.5,0.5$ & & & \\
\hline F16 & & & & & & $2.6,2.5$ & 0.03 & \\
\hline$F 17$ & 2.2 & & & & $0.3,0.6,0.4$ & & & \\
\hline F18 & & & & & & & 0.02 & \\
\hline
\end{tabular}

